\title{
Feeding and masking selection in Inachus phalangium (Decapoda, Majidae): dressing up has never been so complicated
}

\author{
Rocco Rorandelli*, Marina Gomei, Marco Vannini, Stefano Cannicci \\ Dipartimento di Biologia Animale e Genetica 'Leo Pardi', Università degli Studi di Firenze, Via Romana 17, \\ 50125 Firenze, Italy
}

\begin{abstract}
We investigated the choice preferences exhibited by the spider crab Inachus phalangium when using algae for feeding and masking, together with the pattern of decoration present on the body surface and the morphology of the setae, which are used to attach masking material. We showed that feeding and masking preferences are decoupled, and that $I$. phalangium exploited the algal nutritional and chemical properties differently. When feeding, the crab revealed a differential choice among the offered algae, preferring the protein-rich cyanobacteria. When decorating, both algal components that match the background and the Phaeophyta Dictyota dichotoma, which acts as a chemical deterrent against predators, were actively chosen. At the same time, decoration in I. phalangium was used as a short-term food store. We also provided evidence that masking patterns varied in different body regions, depending on the functional morphology of the hooked setae. This work discusses the origin and evolution of the decorative habit, showing for the first time that decoration is a multifaceted mechanism, tightly linked with morpho-functional and behavioural adaptations, and that masking material can also be used as a food store.
\end{abstract}

KEY WORDS: Chemically mediated defence - Decoration · Dictyota - Functional morphology · Spider crab

\section{INTRODUCTION}

Camouflage, also referred to as decoration and masking (sensu Woods \& McLay 1994), is common among marine invertebrates and represents an effective mechanism to reduce predation (Stachowicz \& Hay 1999, Cruz-Rivera 2001). In particular, crabs evolved highly specific camouflaging behavioural and morphological traits (Cruz-Rivera 2001). Species belonging to the Homolidae and Dromiidae families conceal themselves from predators by covering their carapaces with a sponge held in place by their last pair of modified walking limbs (Wicksten 1980); however, true decorator crabs are the ones belonging to the Majidae family, whose members decorate their exoskeletons with algae and other material through specialized hooked setae present on their bodies
(Wicksten 1980, 1983, 1993, Woods \& McLay 1994). Decoration can be either an active process, in which crabs collect the decorative material, manipulate it and then attach it to the hooked setae (Wicksten 1983), or a passive one, in which the crab shell acts as a suitable substratum for the spontaneous settlement of epibionts (Dudgeon 1980). In both cases, decoration seems to be effective in camouflaging crabs from visual predators by supplying a cryptic colouration that matches the background. Furthermore, when specific materials such as toxic algae or sponges are used, they can provide an outfit unpalatable for predators (Wicksten 1980, Maldonado \& Uriz 1992, Stachowicz \& Hay 1999). Generally, it is assumed that decoration reduces predation (Wicksten 1980, 1983), but some authors also suggest that the masking habit might have evolved as a by-product of storing food on the body for later 
consumption (Woods \& McLay 1994), as is the case for the majid Podochela hemphilli (Wicksten 1980). The evolution of this trait is debatable and will not be elucidated until an unequivocal phylogeny is provided (Woods \& McLay 1994).

Among majids, all the members of the genus Inachus retain an extensive decorative habit and are best suited for investigating those aspects controlling and defining this characteristic. In particular, the spider crab Inachus phalangium (Fabricius, 1775) has been the subject of a variety of studies on many aspects of its biology, from reproduction to social structure (Weinbauer et al. 1982, Diesel 1986a,b, Jones \& Hartnoll 1997). This small majid, common in the rocky Mediterranean and north-eastern Atlantic subtidal zones at depths of 0.5 to $20 \mathrm{~m}$ (Hartnoll 1970, Udekem d'Acoz 1999), is often found in association with the snakelocks sea anemone Anemonia viridis (Forsskål, 1775) (Wirtz $\&$ Diesel 1983). Mainly active at night, I. phalangium leaves the inhabited anemone to perform browsing loops, for feeding and decoration purposes (Diesel 1986b). Males are more vagile and move to and from sea anemones in search for receptive partners. Females, however, reside in the same anemone for longer periods (Diesel 1986a).

As with most majids, algae are the major component of the diet of Inachus phalangium and also represent an abundant and readily available source of decorating material (Hartnoll 1963). Studies have shown that other majids choose between using algae either for feeding or decoration (Stachowicz \& Hay 1999, Cruz-Rivera 2001), but no data are available for I. phalangium.

We investigated some aspects of the relationship between Inachus phalangium and the algal component of its natural environment, specifically concentrating on feeding and camouflaging. In particular, we tested for (1) the presence and degree of microhabitat preference and algal preference when feeding and masking, (2) the decorative patterns on different body regions, and (3) the functional morphology of the hooked setae used for decoration.

\section{MATERIALS AND METHODS}

Feeding and masking preferences. The aim of these experiments was to test whether Inachus phalangium prefers different microhabitats and different algae when feeding and masking. This was achieved in captivity by offering I. phalangium a limited selection of habitats and algae, and observing its behaviour. Feeding was defined as the active collection of material from the substrate and its subsequent consumption, while decoration was the set of actions through which masking material was collected from the substratum, passed to the mouthparts for a preliminary preparation and finally placed on the exoskeleton (Wicksten 1993).

Algae, crabs and sea anemones used in all the experiments were collected at Fortullino (Leghorn, Italy) at depths of 5 to $10 \mathrm{~m}$ during SCUBA dives. Samples were transported to the laboratory of the Department of Animal Biology and Genetics, University of Florence, where experiments took place.

To supply the experimental tanks with the most common algae present in the natural environment of Inachus phalangium, an algal assemblage survey was carried out at the collection site, with a total of 4 SCUBA dives performed between March and April 2004. During each dive, 2 researchers moving along a $10 \mathrm{~m}$ linear transect at depths of 5 to $10 \mathrm{~m}$, randomly selected five $25 \times 25 \mathrm{~cm}$ squared areas where all the present macroalgae were visually identified. Unknown samples were collected and later identified. These surveys showed that $85.2 \%$ of the total algal coverage could be assigned to the following 5 categories: green filamentous algae $(2.2 \pm 2.2 \%, \mathrm{SE})$, cyanobacteria $(5.9 \pm 2.2 \%)$, red filamentous algae $(16.7 \pm 7.2 \%)$, encrusting coralline algae $(19.6 \pm 5.4 \%)$ and 2 species of brown algae (Dictyota dichotoma, $22 \pm 5.2 \%$; Stypocaulon scoparia, $18.8 \pm 4.8 \%$ ).

Two experiments were then designed: the sector preference experiment and the algal manipulation experiment. The experimental apparatus consisted of tanks $(80 \times 30 \times 40 \mathrm{~cm})$ organized into 3 distinct sectors of approximately the same surface area, each characterized by the presence of different algal phyla. In particular, one sector primarily comprised a representative of the green filamentous algae (Cladophora sp.) and cyanobacteria; another sector contained red filamentous algae, specifically Ceramium sp., Antithamnion sp., Herposiphonia sp., Dasya sp., and encrusting coralline algae (Corallinales); while the last sector contained 2 species of brown algae, Dictyota dichotoma and Stypocaulon scoparia. The position of the different sectors in the aquaria was randomly assigned in order to avoid a selection biased by spatial position, and algae were provided in equal abundances in the different tanks and tests.

Immediately after collection, crabs were measured, sexed and marked, so that they could be tracked individually. In each aquarium, 4 or 5 adult individuals of Inachus phalangium (8 to $15 \mathrm{~mm}$ carapace width) were present with a female to male ratio of $2: 2$ or $3: 2$. In addition, samples of Anemonia viridis were placed in each tank to recreate conditions close to the natural ones. Anemone density, crab density and crab sex ratio were chosen according to the average values recorded in the field. 
Tanks were kept at a constant temperature of $18^{\circ} \mathrm{C}$ and under controlled light:dark conditions. To observe crab activity during diurnal and nocturnal hours, aquaria were kept in a room supplied with a day:night timer, with light hours from 00:00 to 12:00 h and darkness from 12:00 to 00:00 h. Animals were exposed to this altered photoperiod for at least $3 \mathrm{~d}$ before observations. Data were collected from 2 observations a day, one during the light hours (day) and one $4 \mathrm{~h}$ after the light was turned off (night). During the light hours the observer was concealed by white panels surrounding the aquaria that were provided with small viewing holes. In darkness, a red beam flashlight offered enough light without disturbing animals. During the experiments, crabs and anemones were fed with clam flesh once a week, and the tank water was periodically changed.

Sector preference experiment: To test the null hypothesis that crabs did not show any preference in selecting any of the 3 microhabitats when feeding and decorating, crabs were followed during each observation for $60 \mathrm{~s}$ and their activity and position in the aquaria recorded. All the performed behavioural traits were noted, but only feeding and masking were computed in the subsequent analyses. Overall, 80 observatory sessions were done in March-May 2004 and in November-December 2004. A total of 18 crabs, distributed among 4 tanks, each containing 4 anemones, were employed for this test.

Algal manipulation experiment: To test that crabs did not show any algal preference when feeding and decorating, we employed the same experimental protocol used in the sector preference experiment, except that when crabs were seen feeding or decorating, the observer took note of the manipulated algae.

As in the previous experiment, 80 observatory sessions were done in March-May 2004 and in November-December 2004, with a total of 18 crabs, in 4 tanks, with each containing 4 anemones.

Patterns of decoration. The body decoration pattern of 15 adult individuals of Inachus phalangium (6 females and 9 males) was investigated. Crabs collected from their natural habitat were stocked in tanks devoid of any algae for $3 \mathrm{wk}$. After this period of time, crabs were individually inspected to confirm that all the preexistent masking material had been completely lost (data not shown) due to accidental loss or removal by crabs, or both (Wirtz \& Diesel 1983). This methodology proved effective in removing decoration without the need of any mechanical manipulation, which might cause damage to exoskeleton and setae. In order to avoid starvation, which might affect feeding choice and antipredator behaviour (Vadas et al. 1994, Cronin \& Hay 1996), crabs were fed clam muscles thrice weekly. After the algal removal pre-treatment, crabs were stocked for $30 \mathrm{~d}$ in aquaria supplied with the same algal components used in the feeding and masking preferences experiment. To reduce stress in the crabs, no initial algal coverage assessment was performed. However, crabs are known to be also covered with inorganic sediment and sponges (Wirtz \& Diesel 1983, Maldonado \& Uriz 1992). While visible sponges were not present in our experimental setting, it cannot be excluded that gemmules or larvae were attached to the living algae and were able to settle on crabs during the course of the experiment. As to the presence of sediment, the experimental set-up used algae collected in nature and still attached to their rocky substratum, which also included undetermined amounts of inorganic component. At the end of the trial, crabs were immediately examined to avoid any possible loss of their decorative material. Algae samples were removed from the crabs and identified using a microscope $(100 \times$ magnification). Algal topography was then derived from a map of the crab body surface. In particular, algae were collected from 7 distinct body regions: dorsal carapace, rostrum, cheliped and pereopods II to V (see Fig. 3 for a schematic anatomical representation).

Hooked setae scanning electron microscope analysis. Hooked setae are present on the dorsal carapace and on all limbs of Inachus phalangium. Scanning electron microscope (SEM) images of these structures were taken from 2 adult individuals of I. phalangium. Specimens were preserved in $75 \%$ ethanol before removing the algal cover with forceps under a dissecting microscope to expose the underlining setae without damaging them. Specimens were then prepared for SEM analysis by the Inter-departmental Service for Microscopy and Micro-analysis at the University of Florence. All 7 parts analysed in the patterns of decoration experiment (dorsal carapace, rostrum, cheliped, and pereopods II to V) were inspected by SEM.

Data were treated using the freeware imaging software ImageJ ver. 1.33u. Density, morphology and length of the setae were measured for all the specimens. Density was computed by randomly selecting 4 areas of the body region image and counting the number of setae present in an area of $50 \times 50 \mu \mathrm{m}$. Morphology was qualitatively described on the basis of the degree of curvature of the represented setae. Curvature estimates resulted in 3 classes: (1) strongly twisted (setae almost bending on themselves), (2) twisted (hook-like setae), and (3) straight (weakly curved to linear setae). Length was calculated by randomly selecting 10 setae of the represented body region and calculating their mean length.

Data analysis. During sector preference and algal manipulation experiments, data were recorded only when crabs were not in contact with any sea anemone, 
as associated crabs were not performing any active selection of algae. An ANOVA nested model with repeated measures on a cross factor was used to test for microhabitat preference. The factors considered were aquarium and sex of the individuals (nested into the factor aquarium). Since analysed data were proportions of time spent in the different microhabitats, an arcsine square root transformation was employed before ANOVA. The same test was used when testing for differences among the single manipulated algae when crabs were feeding and masking, and to determine if this preference varied among females and males, nested in the factor aquarium. The normality of distribution was tested with Shapiro's test.

In the hooked setae analysis experiment, a 2-way ANOVA was employed to test for differences among body parts in the percentage cover of the principal masking components. A Tukey post hoc analysis was used. Factors in this test were body regions $(7$ levels, fixed and orthogonal) and sex (2 levels, fixed and orthogonal). To reduce the number of showed contrast tests, we pooled all those levels that were not significantly different from each other. Before analysis, variance homogeneity was tested using Shapiro's test and data were transformed to $x^{\prime}=\log (x+1)$ to remove heteroscedascity (Underwood 1997). ANOVA tests were performed using the software JMP IN release 5.1 (SAS Institute).

\section{RESULTS}

\section{Feeding and masking preferences}

Sector preference experiment

Registered frequencies of feeding acts were different in the 3 microhabitats $\left(F_{2,9}=18.53 ; \mathrm{p}=0.006\right)$, while no differences were found either between sexes $\left(F_{4,10}=\right.$ $2.31 ; \mathrm{p}=0.12)$ or among aquaria $\left(F_{3,10}=0.33 ; \mathrm{p}=0.40\right)$. Frequencies of masking acts were also different in the 3 microhabitats $\left(F_{2,9}=33.43 ; \mathrm{p}<0.0001\right)$, while no differences were found between sexes $\left(F_{4,10}=0.90 ; \mathrm{p}=\right.$ $0.40)$ or among aquaria $\left(F_{3,10}=0.23 ; \mathrm{p}=0.87\right)$. In particular, crabs preferred to feed in Sectors 1 and 2 (the microhabitats dominated by Chlorophyta/cyanobacteria and Rhodophyta, respectively), while decorating was performed mainly in Sector 3 (the microhabitat dominated by Phaeophyta) (Fig. 1).

\section{Algal manipulation experiment}

We analysed the main algal components that the crabs were actually seen manipulating while feeding

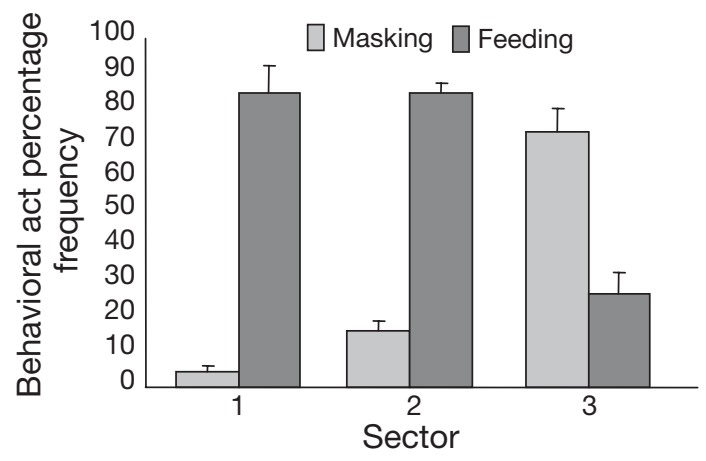

Fig. 1. Inachus phalangium. Percentage frequency (mean + $\mathrm{SE}$ ) of feeding and decoration behavioural acts performed in the 3 sectors $(\mathrm{n}=18)$. Sector 1: Chlorophyta/cyanobacteria; Sector 2: Rhodophyta; Sector 3: Phaeophyta

and masking. When feeding, crabs showed a preference for cyanobacteria and Stypocaulon scoparia $\left(F_{4,7}=1316.81 ; \mathrm{p}<0.0001\right.$; Fig. 2$)$, whereas when masking, Dictyota dichotoma was preferred to any other algae $\left(F_{4,7}=155.92 ; \mathrm{p}<0.0001 ;\right.$ Fig. 2$)$, although these brown algae were never used by crabs for feeding. Cladophora sp. and red filamentous algae were used in a similar amount for both feeding and masking, even if the former were only rarely used (Fig. 2). Encrusting coralline algae were instead never manipulated by crabs, neither when feeding nor when decorating. Males and females chose the same algal components when performing masking and feeding as no significant difference was recorded between sexes $\left(F_{4,10}=2.30 ; \mathrm{p}=0.13\right.$ and $F_{4,10}=0.53 ; \mathrm{p}=0.72$, for feed-

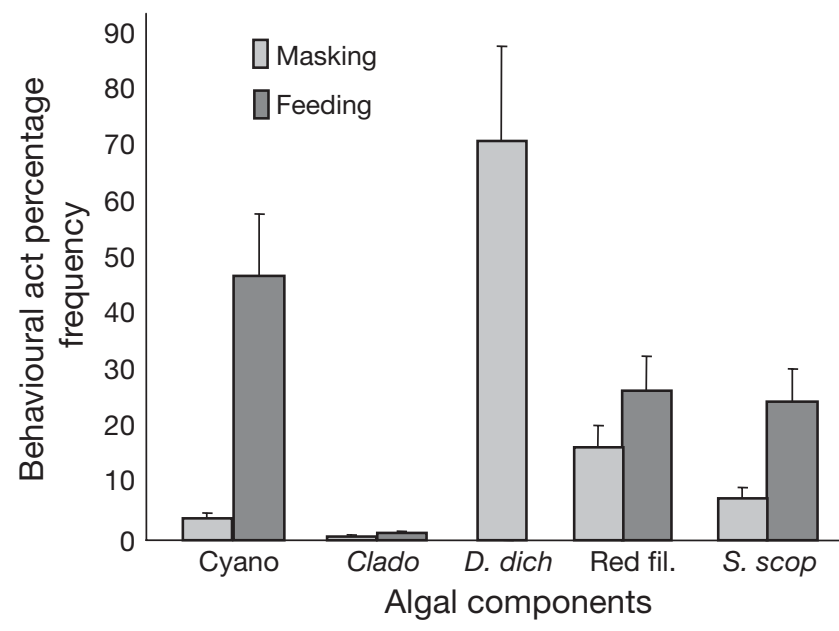

Fig. 2. Inachus phalangium. Percentage frequency of feeding and decoration behavioural acts involving manipulation of algal species $(\mathrm{n}=18)$. Decorative components: Cyano = cyanobacteria; $C l a d o=$ green algae Cladophora sp.; $D$. dich $=$ brown algae Dictyota dichotoma; red fil. = red filamentous algae; $S$. scop = brown algae Stypocaulo scoparia 
ing and masking, respectively) and among aquaria $\left(F_{3,10}=0.53 ; \mathrm{p}=0.67\right.$ and $F_{3,10}=0.46 ; \mathrm{p}=0.72$, for feeding and masking, respectively).

\section{Patterns of decoration}

The average abundances of each algal category on the entire body and the single regions were calculated for the 15 crabs analysed. The resulting 5 algal components were red filamentous algae, Dictyota dichotoma, Stypocaulon scoparia, cyanobacteria, and encrusting coralline algae; however, sponges and raw sediment were also taken into account, since they represented a discrete percentage of the decorative material. Among these 7 elements, D. dichotoma, red filamentous algae, red encrusting coralline algae and sediment together accounted for $91.1 \%$ of the total body coverage, and were taken into account in our analysis.

By far, Dictyota dichotoma and the red filamentous algae were the most abundant among the detected decorative material (with a mean value [ $\pm \mathrm{SE}$ ] of $28.7 \pm$ 4.7 and $40.9 \pm 10.7 \%$, respectively, of the total body masking material), and thus, their mean total body coverage represented nearly $70 \%$ of the total. Red encrusting coralline algae had a value of $10.5 \pm 6.7 \%$ of the total algal cover. The value for sediment, consisting of incoherent inorganic matter, was $13.0 \pm 5.4 \%$.

A 2-way ANOVA showed that decorative elements had a different abundance between sexes relative to the body regions analysed. A pair-wise test showed that Dictyota dichotoma was present on more of the analysed body regions than on the last 3 pereopods, and was present more in females than in males. In particular, these brown algae were frequent in discrete areas on the carapace, abundant on pereopod II, cheliped, and rostrum, and absent in pereopods III to V (Table 1, Fig. 3).

The frequency of red filamentous algae was significantly different among body regions, irrespective of sex. A contrast test showed that these algae were significantly more abundant on the carapace, cheliped and pereopods III to $\mathrm{V}$, but were infrequent on the rostrum and pereopod II (Table 1, Fig. 3).

A different distribution was revealed by the red encrusting coralline algae, which on both female and male crabs were almost exclusively present on pereopods III to V, while absent on the cheliped and pereopod II (Table 1, Fig. 3).

Finally, sediment was more abundant on females than on males, and had a significantly different distribution in the different body regions (Table. 1, Fig. 3). This non-algal component was frequent on the rostrum and the carapace, well represented on the last 3 pereopods, but as with the red encrusting coralline, absent on the cheliped and pereopod II.
The remaining decorative components accounted for less than $10 \%$ of the total body coverage. Cyanobacteria were moderately present only on the rostrum and carapace, poorly represented on all 4 pereopods, and absent on chelipeds. The presence of Stypocaulon scoparia as decorative material was found only on the cheliped and pereopod II and was almost absent on the carapace. Finally, sponges were only sporadically present on the rostrum and carapace (Fig. 3).

Table 1. Results of 2-way ANOVA for the main decorative components. Body regions: Ros = rostrum; Car = carapace; Che $=$ cheliped; pII to $\mathrm{pV}$ : pereopods II to $\mathrm{V}$, respectively. Only significant contrast test results are shown

\begin{tabular}{|c|c|c|c|c|}
\hline Source & $\mathrm{df}$ & MS & $F$ & $\mathrm{p}$ \\
\hline \multicolumn{5}{|l|}{ Dictyota dichotoma } \\
\hline Sex & 1 & 7.31 & 4.56 & 0.03 \\
\hline Body part & 6 & 47.41 & 29.60 & $<0.0001$ \\
\hline Sex $\times$ Body part & 6 & 0.97 & 0.60 & 0.72 \\
\hline Residual & 91 & 1.60 & & \\
\hline Total & 104 & & & \\
\hline Contrast test & $t$ & $\mathbf{p}$ & & \\
\hline Car + Che vs. pIII-pV & 9.87 & 0.001 & & \\
\hline Ros vs. pIII-pV & 8.01 & 0.001 & & \\
\hline PII vs. pIII-pV & 10.28 & 0.001 & & \\
\hline Females vs. Males & 2.53 & 0.01 & & \\
\hline \multicolumn{5}{|l|}{ Red filamentous } \\
\hline Sex & 1 & 1.37 & 0.32 & 0.57 \\
\hline Body part & 6 & 14.66 & 3.44 & 0.004 \\
\hline Sex $\times$ Body part & 6 & 0.14 & 0.03 & 0.99 \\
\hline Residual & 91 & 4.25 & & \\
\hline Total & 104 & & & \\
\hline Contrast test & $t$ & $\mathbf{p}$ & & \\
\hline Car + Che vs. pII & 2.54 & 0.012 & & \\
\hline Car + Che vs. Ros & -2.79 & 0.006 & & \\
\hline pII vs. pIII-pV & -3.36 & 0.001 & & \\
\hline Ros vs. pIII-pV & 3.62 & $<0.001$ & & \\
\hline \multicolumn{5}{|l|}{ Red encrusting coralline } \\
\hline Sex & 1 & 0.24 & 0.11 & 0.73 \\
\hline Body part & 6 & 6.56 & 3.01 & 0.009 \\
\hline Sex $\times$ Body part & 6 & 0.39 & 0.18 & 0.98 \\
\hline Residual & 91 & 2.17 & & \\
\hline Total & 104 & & & \\
\hline Contrast test & $t$ & $\mathbf{p}$ & & \\
\hline Car + Che vs. pIII-pV & 3.50 & $<0.001$ & & \\
\hline Ros vs. pIII-pV & -2.45 & 0.016 & & \\
\hline pII vs. pIII-pV & -3.09 & 0.002 & & \\
\hline \multicolumn{5}{|l|}{ Sediment } \\
\hline Sex & 1 & 15.03 & 6.42 & 0.013 \\
\hline Body part & 6 & 9.80 & 4.18 & $<0.001$ \\
\hline Sex $\times$ Body part & 6 & 3.00 & 1.28 & 0.274 \\
\hline Residual & 91 & 2.34 & & \\
\hline Total & 104 & & & \\
\hline Contrast test & $t$ & $\mathbf{p}$ & & \\
\hline pII vs. pIII-pV & -2.16 & 0.033 & & \\
\hline pII vs. Car + Che & -2.62 & 0.010 & & \\
\hline pII vs. Car & 4.37 & $<0.001$ & & \\
\hline pII vs. Ros & -2.10 & 0.037 & & \\
\hline Che vs. Car & 4.20 & $<0.001$ & & \\
\hline Females vs. Males & 2.53 & 0.012 & & \\
\hline
\end{tabular}


Hooked setae scanning electron microscope analysis

SEM images showed a conspicuous differentiation of setae morphology and spatial distribution among the relative body regions (Fig. 3). Morphological qualitative descriptions and quantitative measurements of the setae were obtained from the SEM images of the 7 distinct body areas. Average setae length was $328 \pm 166$ $( \pm \mathrm{SE}) \mu \mathrm{m}$, while density was $89.9 \pm 54.3$ setae $\mathrm{mm}^{-2}$. However, setae from different regions showed a substantial variation in their degree of curvature, density and length (Table 2). Setae from the carapace were
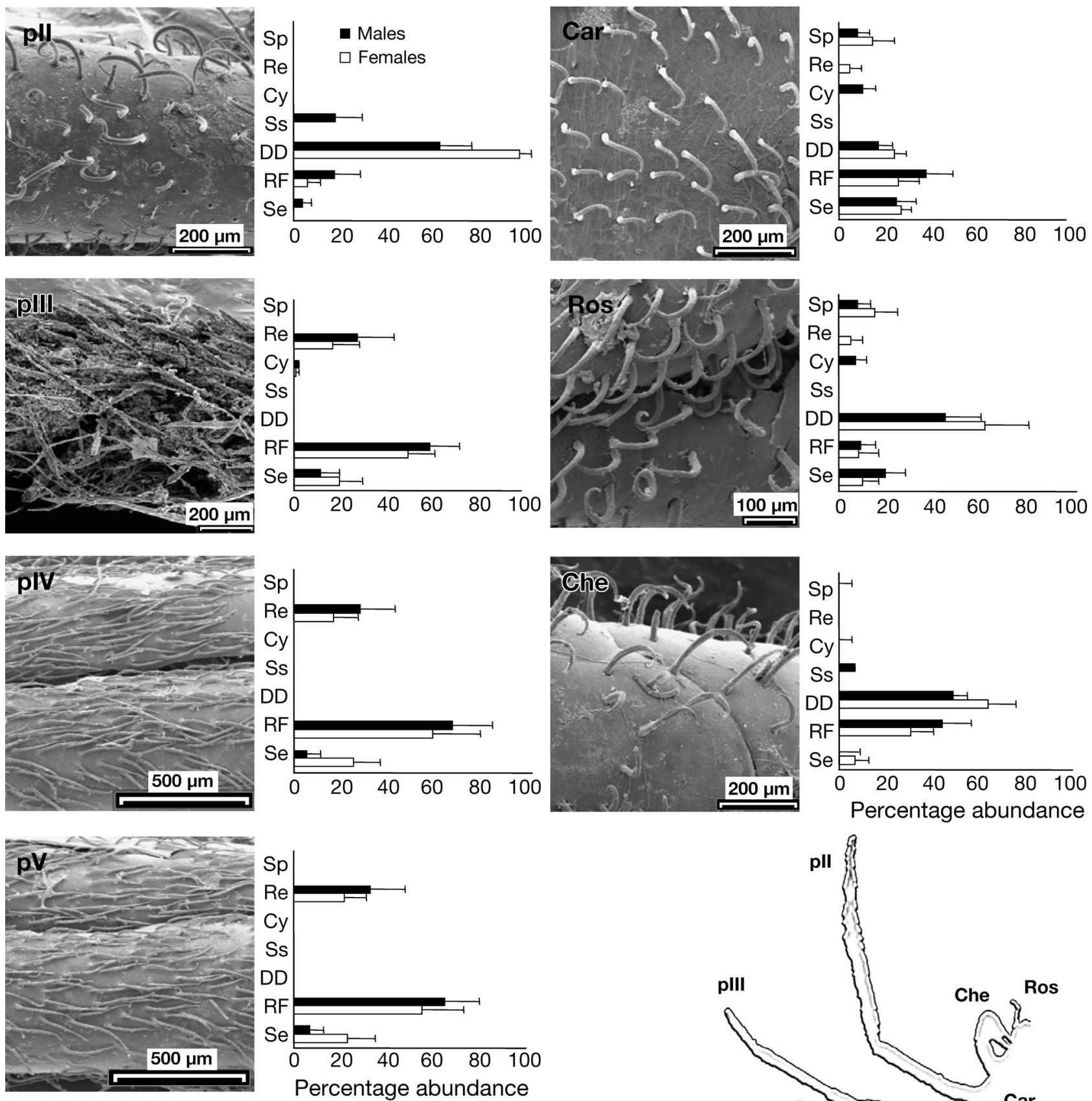

Fig. 3. Inachus phalangium. Decorative element percentage abundance and SEM photographs of hooked setae in 7 distinct body regions (see Table 1) for females and males. Mean + SE are shown in the graphs. Decorative components: $\mathrm{Sp}=$ sponges; $\mathrm{Re}=$ Red encrusting coralline algae; $\mathrm{Cy}=$ Cyanobacteria $; \mathrm{Ss}=$ Stypocaulon scoparia $; \mathrm{DD}=$ Dictyota dichotoma $;$ $\mathrm{RF}=$ Red filamentous algae; $\mathrm{Se}=$ sediment

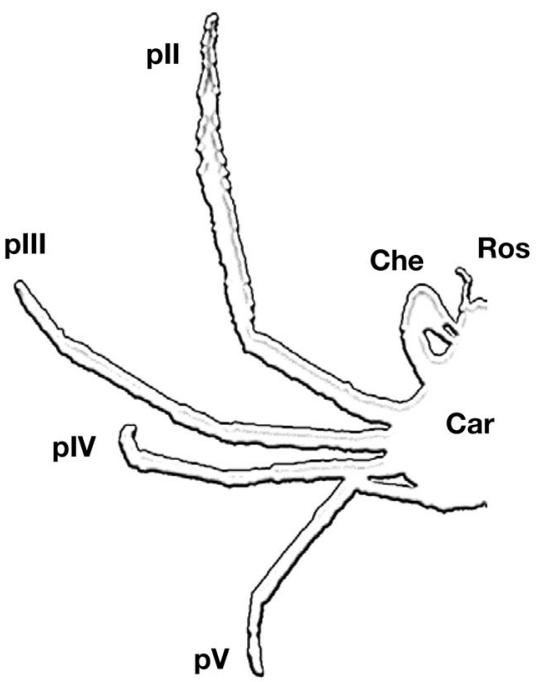


Table 2. Setae morphological characterizations in 7 distinct body regions (see Table 1). Mean \pm SE given for average length $(\mathrm{mm})$ and density (setae $\mathrm{mm}^{-2}$ ). DC: degree of curvature; $\mathrm{HH}$ : very twisted; $\mathrm{H}$ : twisted; L: straight or very poorly bent

\begin{tabular}{|lccr|}
\hline Body region & Avg. length & DC & \multicolumn{1}{c|}{ Density } \\
\hline Ros & $384.0 \pm 33.0$ & HH & $20.6 \pm 4.8$ \\
Car & $307.0 \pm 15.6$ & HH & $101.2 \pm 2.2$ \\
Che & $192.0 \pm 16.6$ & HH & $125.5 \pm 1.3$ \\
pII & $671.0 \pm 38.0$ & H & $16.1 \pm 1.4$ \\
pIII & $321 \pm 20.6$ & L & $79.9 \pm 3.4$ \\
pIV & $208.5 \pm 8.9$ & L & $148.0 \pm 5.0$ \\
pV & $214.5 \pm 9.0$ & L & $140.4 \pm 4.8$ \\
\hline
\end{tabular}

strongly twisted, shorter and with a high density (Fig. 3A). Setae from the rostrum were similar in curvature, longer and with a very low density (Fig. 3B). Setae covering the cheliped had a very high curvature, a high density, but had the shortest length (Fig. 3C). Pereopod II setae had the longest length and the lowest density per surface unit, and a high curvature (Fig. 3D). Finally, setae from pereopods III to V were all weakly curved or almost linear, with pereopod III retaining a longer length and a reduced density compared with pereopods IV and V (Fig. 3E-G).

\section{DISCUSSION}

The sector preference experiment showed that Inachus phalangium selects different microhabitats when feeding and decorating. In particular, sectors dominated by green algae and cyanobacteria and by red algae were mainly used for feeding, while the sector containing brown algae was selected when decorating. In the algal manipulation experiment there was a better definition of the taxa used for such functions. Some algae are mostly used for one task, while others were used both for feeding and decorative materials. We can infer that $I$. phalangium does not merely respond to the availability of algae in the environment, but adopts a double selection strategy, targeting different algae for feeding and masking purposes. When feeding, cyanobacteria and red filamentous algae were the preferred algal taxa. Red filamentous algae like Ceramium spp. and Herposiphonia spp. are known to provide a source of fast-assimilating carbohydrates (Kim \& Fritz 1993, Cannicci et al. in press), while cyanobacteria represent a protein-rich source (Kennish et al. 1996, Cannicci et al. in press). Cyanobacteria were seldom used by I. phalangium as decorative material, while red filamentous algae constituted a frequent material of choice. The brown alga Stypocaulon scoparia was used for both purposes as well, but significantly more for feeding. Taking into consideration the small size of the chelae of $I$. phalangium, we hypothesized that crabs consumed epibionts and young propagules when manipulating such a thick cortiated macroalgal species, as has been shown in other crabs (Kennish et al. 1996).

Some algae present in the experimental aquaria (Cladophora sp., the red encrusting coralline algae and Dictyota dichotoma) were never used by Inachus phalangium as a food source. We are not able to provide any hypothesis explaining the lack of use of the nutrient-rich and easy to manipulate Cladophora sp. (Cannicci et al. in press); however, the red encrusting coralline algae proved to be as difficult to manipulate and ingest as it is for many other crabs (Cannicci et al. 2002). Dictyota dichotoma was strictly used for masking purposes, and no crabs were ever seen feeding on it. This brown alga produces dictyol E (Gedara et al. 2003), a cytotoxic diterpene present in other Dictyota species, known to be avoided by omnivorous fishes. Corroborating evidence comes from young individuals of the spider crab Libinia dubia living in the western Atlantic Ocean and from the spider crab Macropodia rostrata, sympatric to I. phalangium in the Mediterranean Sea, which selectively choose to decorate with D. menstrualis (Stachowicz \& Hay 1999) and D. linearis (Cruz-Rivera 2001), respectively, thus reducing predation pressure. We hypothesize that I. phalangium, like $L$. dubia and $M$. rostrata, exploits the cytotoxic properties of $D$. dichotoma to reduce predation risk.

No differences were recorded between females and males of Inachus phalangium in both experiments, showing that feeding and masking selections are a crucial part of the biology of this crab.

In the pattern of decoration experiment we highlighted the presence of 7 masking elements on the body surface of the experimental crabs. Among these, Dictyota dichotoma, red filamentous algae, red encrusting coralline algae and sediment were the most abundant. Although masking elements were present on the entire exoskeleton of Inachus phalangium, their distribution varied among different body regions. In particular, I. phalangium exhibited a mutual exclusion of the distribution of $D$. dichotoma, which was confined to the front-most areas of the body, and of the Rhodophyta, which was mainly present in the last 3 pereopods. The distribution pattern of the various algae can thus be readily explained by looking at the required hooked setae morphology. D. dichotoma is the only foliose alga among the ones investigated, and the long and sparse hooked setae present on the carapace, rostrum, cheliped and pereopod II seem optimal to fasten the rather stout and bulky pieces of these brown algae. In nature, I. phalangium can often be seen resting between the tentacles of Anemonia viridis (Wirtz \& Diesel 1983). When in this position, the only 
visible parts of its body are the rostrum and the first 2 pairs of limbs, latter usually being kept wide open and raised (Rorandelli et al. in press). Moreover, when in this position crabs often slowly sway, mimicking the movement of an algal branch in the water current (Rorandelli et al. in press). We conclude that the frontal area might be a strategic spot for decoration in I. phalangium, as D. dichotoma is highly represented in this area.

Hence, decoration with Dictyota dichotoma, possibly used to reduce predation risk, is located on body areas exposed to predators. These areas not only match the background, making the crab less visible, but also send chemically detectable repulsive signals. Chemically mediated camouflage is considered rather infrequent in both marine and terrestrial realms (Stachowicz \& Hay 1999), but further studies might reveal it to be a shared element among majids. On the other hand, the last 3 limbs are covered with more linear and dense setae, which form a compact coarse cylinder to which encrusting coralline and red filamentous algae could find an ideal anchoring substratum.

Cyanobacteria are infrequent as decorative material and are mainly restricted to the rostrum and the carapace, where hooked setae show the highest curvature. The small pellets made by Inachus phalangium when feeding on cyanobacteria require a strong hold to remain attached to the exoskeleton.

This highly specific algal topography was recorded in both females and males; however, females showed a higher presence of some masking elements, specifically sediment and Dictyoma dichotoma. This result may seem to contradict the algal manipulation experiment, where no differences in feeding or masking selection were recorded between sexes. However, this divergence is related to the different nature of these 2 experiments: while the first offered a macroscopic view of the crabs' preferences, the latter microscopically identified the real nature of the algal coverage, offering a greater resolution. In addition, a higher presence of sediments could be explained by the more sedentary lifestyle of females, as hypothesized for other spider crabs (Maldonado \& Uriz 1992). In the congeneric Inachus aguiarii, a higher degree of decoration of females is supposed to be a means to reduce predation pressure (Maldonado \& Uriz 1992).

In addition, some masking elements found on the crabs investigated were not present in the experimental apparatus or were never manipulated by crabs. Decoration is not always an active process accomplished by the crab, and some components might colonize the crabs' exoskeletons without any active contribution. Red encrusting coralline algae, present in aquaria, and sponges, probably represented by propagules, were never used by crabs as masking materials, but formed part of the recorded decorative elements. Their adaptive significance is clear; they provided an advantageous means for mimicking the surroundings.

Differential body pattern decoration is known in other majid species (Dudgeon 1980), but the proximate mechanisms have never been studied. Previous works on other spider crabs have defined the distribution of the hooked setae on the exoskeleton (Woods \& Page 1999), but no differences were described at the morphological level. Furthermore, no correlations have been made with the different algal components present in these regions, although they have been suggested by some authors (Woods \& McLay 1994). The present study is the first attempt to produce a comprehensive scenario to describe the proximate and remote mechanisms of decoration by Inachus phalangium.

Our investigation showed that diet and decoration of Inachus phalangium present some shared elements. This observation, and the fact that $I$. phalangium actively removes and ingests its decoration (Wirtz \& Diesel 1983), suggests that decoration also works as a mechanism to store food, as has been demonstrated for the spider crab Notomithrax ursus (Woods \& McLay 1994). Food storage is advantageous for animals with seasonal food availability or periods of low activity. In effect, one of the costs of the symbiosis of $I$. phalangium with Anemonia viridis is the restriction of food supply, which becomes limited to the area surrounding the host (Wirtz \& Diesel 1983). When associated with A. viridis, crabs normally rest among the urticant tentacles during the light hours, and perform short-range feeding loops outside the anemone only at night (Diesel 1986b, Rorandelli et al. in press). Depending on the location of the host sea anemone, crabs might have a reduced accessibility to the required algae. The storage system of $I$. phalangium could not provide any long-term alternative source of nutrients, but seems optimal when considering the ecology of this species, as it may be forced to withstand short periods of inaccessibility to food when associated with its host.

The present study provides the first evidence of the complexity of decoration in spider crabs. Our data show that such complexity is higher than previously stated by other authors (Wirtz \& Diesel 1983, Kilar \& Lou 1986, Parapar et al. 1997, Cruz-Rivera 2001) and that decoration should be investigated by combining behavioural and functional morphology data. This comprehensive approach, linking behavioural manipulation procedures and body district morphology devoted to either decoration or food storage, proves effective in deciphering the origin and the underlining mechanisms of decoration. The active selection shown by Inachus phalangium when feeding and decorating implies the existence of some recognition mechanisms 
for choosing algae for different functions, and a set of behavioural traits that enable crabs not only to manipulate the decorative material, but also to organize it along a complex body surface and hooked setae topography.

Acknowledgements. We thank Dr. G. Innocenti for the taxonomic identifications and manuscript revision; all the members of the Florence Crab Team, in particular F. Bartolini, and Dr. S. Fratini; A. Pasqualin and F. Todesco for data collection; I. Tëmkin for manuscript revisions; 2 anonymous referees for comments; the Inter-departmental Service for Microscopy and Micro-analysis of the University of Florence. This study was funded by University of Florence and by MURST (COFIN project). R.R. was supported by a PhD fellowship from the Italian Ministry of Education, University and Research (MIUR).

\section{LITERATURE CITED}

Cannicci S, Gomei M, Boddi B, Vannini M (2002) Feeding habits and natural diet of the intertidal crab Pachygrapsus marmoratus: opportunistic browser or selective feeder? Estuar Coast Shelf Sci 54:983-1001

Cannicci S, Gomei M, Dahdouh-Guebas F, Rorandelli R, Terlizzi A (in press) Influence of seasonal availability and food quality on the diet of an opportunistic feeder, the intertidal crab Pachygrapsus marmoratus. Mar Biol (doi: 10.1007s0027-006-0570-3

Cronin G, Hay ME (1996) Susceptibility to herbivores depends on recent history of both the plant and animal. Ecology 77:1531-1543

Cruz-Rivera E (2001) Generality and specificity in the feeding and decoration preferences of three Mediterranean crabs. J Exp Mar Biol Ecol 266:17-31

Diesel R (1986a) Optimal mate searching strategy in the symbiontic spider crab Inachus phalangium (Decapoda). Ethology 72:311-328

Diesel R (1986b) Population dynamics of the commensal spider crab Inachus phalangium (Decapoda: Maiidae). Mar Biol (Hist Arch) 91:481-489

Dudgeon D (1980) Some inter- and intraspecific differences in the decorating patterns of majid crabs (Crustacea: Decapoda) from the coastal waters of Hong Kong. Marine Biological Workshop, Hong Kong University Press, Hong Kong

Gedara SR, Abdel-Halim OB, el-Sharkawy SH, Salama OM, Shier TW, Halim AF (2003) Cytotoxic hydroazulene diterpenes from the brown alga Dictyota dichotoma. Z Naturforsch 58:17-22

Hartnoll RG (1963) The biology of Manx spider crabs. Proc Zool Soc Lond 141:423-496

Hartnoll RG (1970) The relationship of an amphipod and a spider crab with the snakelocks anemone. Annu Rep Mar Biol Stn Port Erin 83:37-42

Jones DR, Hartnoll RG (1997) Mate selection and mating behaviour spider crabs. Estuar Coast Shelf Sci 44:185-193

Editorial responsibility: Howard Browman (Associate Editorin-Chief), Storebø, Norway
Kennish R, Williams GA, Lee SY (1996) Algal seasonality on an exposed rocky shore in Hong Kong and the dietary implications for the herbivorous crab Grapsus albolineatus. Mar Biol 125:55-64

Kilar JA, Lou RM (1986) The subtleties of camouflage and dietary preference of the decorator crab, Microphrys bicornutus Latreille (Decapoda: Brachyura). J Exp Mar Biol Ecol 101:143-160

Kim GH, Fritz L (1993) A signal glycoprotein with $\alpha$-D-mannosyl residues is involved in the wound-healing response of Antithamnion sparsum (Ceramiales, Rhodophyta). J Phycol 29:85-90

Maldonado M, Uriz MJ (1992) Relationships between sponges and crabs: patterns of epibiosis on Inachus aguiarii (Decapoda: Majidae). Mar Biol 113:281-286

Parapar J, Fernández L, González-Gurriarán E, Muiño R (1997) Epibiosis and masking material in the spider crab Maja squinado (Decapoda: Majidae) in the Ría de Arousa (Galicia, NW Spain). Cah Biol Mar 38:221-234

Rorandelli R, Bartolini F, Gomei M, Cannicci S (in press) Observations in captivity of the activity patterns and resources utilization of the spider crab Inachus phalangium (Decapoda, Majidae). Mar Biol (doi:10.1007s00227-0060550-7)

Stachowicz JJ, Hay ME (1999) Reducing predation through chemically mediated camouflage: indirect effects of plant defences on herbivores. Ecology 80:495-509

Udekem d'Acoz C d' (1999) Inventaire et distribution des crustacés décapodes de l'Atlantique nord-oriental, de la Méditerranée et des eaux continentales adjacentes au nord de $25^{\circ} \mathrm{N}$, Collection Patrimoines Naturels 40, Paris, SPN/IEGB/MNHN

Underwood AJ (1997) Experiments in ecology: their logical design and interpretation using analysis of variance. Cambridge University Press, Cambridge

Vadas RL, Burrows MT, Hughes RN (1994) Foraging strategies of dogwhelks, Nucella lapillus (L.): interacting effects of age, diet and chemical cues to the threat of predation. Oecologia 100:439-450

Weinbauer G, Nussbaumer V, Patzner RA (1982) Studies on the relationship between Inachus phalangium (Maiidae) and Anemonia sulcata in their natural environment. PSZN I: Mar Ecol 3:143-150

Wicksten MK (1980) Decorator crabs. Sci Am 242:146-154

Wicksten MK (1983) Camouflage in marine invertebrates. Oceanogr Mar Biol Annu Rev 21:177-193

Wicksten MK (1993) A review and a model of decorating behavior in spider crabs (Decapoda, Brachyura, Majidae). Crustaceana 64:314-325

Wirtz P, Diesel R (1983) The social structure of Inachus phalangium, a spider crab associated with the sea anemone Anemonia sulcata. Z Tierpsychol 62:209-234

Woods CMC, McLay CL (1994) Use of camouflage materials as a food store by the spider crab Notomithrax ursus (Brachyura: Majidae). N Z J Mar Freshw Res 28:97-104

Woods CMC, Page MJ (1999) Sponge masking and related preferences in the spider crab Thacanophrys filholi (Brachyura: Majidae). Mar Freshw Res 50:135-143

Submitted: March 29, 2006; Accepted: September 24, 2006 Proofs received from author(s): April 16, 2007 